\title{
Effects of Preharvest Calcium Foliar Sprays on Several Fruit Quality Attributes and Nutritional Status of the Kiwifruit Cultivar Tsechelidis
}

\author{
Nikolaos Koutinas \\ Department of Crop Production, Alexander Technological Educational \\ Institute of Thessaloniki, P.O. Box 141, 57400, Thessaloniki, Greece
}

Thomas Sotiropoulos ${ }^{1}$

Pomology Institute, National Agricultural Research Foundation, R.R. Station 38, Naoussa, 59200 Naoussa, Greece

\section{Antonios Petridis \\ School of Agriculture, Aristotle University of Thessaloniki, 54124, Thessaloniki, Greece \\ Dimitrios Almaliotis \\ Soil Science Institute (N.AG.RE.F.), P.O. Box 60435, Thermi-Thessaloniki, 57001 Greece}

Emmanuil Deligeorgis and Ioannis Therios

Laboratory of Pomology, School of Agriculture, Aristotle University of Thessaloniki, 54124 Thessaloniki, Greece

\section{Nikolaos Voulgarakis \\ Department of Logistics, Alexander Technological Educational Institute of Thessaloniki (Katerini outlier), 60100, Katerini, Greece}

Additional index words. Actinidia deliciosa, antioxidant power, ascorbic acid, calcium, phenols

\begin{abstract}
The effect of various commercial calcium (Ca) -containing products applied as preharvest foliar sprays on several fruit quality attributes and nutritional status of the kiwifruit cultivar Tsechelidis for a 2-year period is reported. Foliar application of all Ca products plus boron did not affect mean fruit weight compared with the control. During the first year, the highest flesh firmness was measured after application of the Cacontaining products Acid CaLMg and Calfruit plus Qualyfruit. During the second year, the highest flesh firmness was measured after application of the product Acid CaLMg. The highest ascorbic acid content and total antioxidant power were recorded after application of the product Chelan CaP. Foliar application of Power-Ca resulted in an increase of $\mathrm{Ca}$ concentration of leaves compared with the control for the first year. During the second year, all Ca-containing products increased Ca concentration of leaves compared with the control. Foliar application of Calfruit plus Qualyfruit, Chelan CaP, Power Ca, and Acid $\mathrm{CaLMg}$ resulted in an increase of $\mathrm{Ca}$ concentration of fruits compared with the control. The efficacy of the foliar sprays on some of the tested parameters varied from year to year indicating the influence of other parameters on vine nutrition.
\end{abstract}

Calcium $(\mathrm{Ca})$ is an important nutrient associated with fruit quality in kiwifruit. Considerable attention has been given to Ca application to kiwifruit since it was found to prolong storability (Basiouny and Basiouny, 2000). Greater $\mathrm{Ca}$ contents in fruit may maintain membrane permeability and slow the ripening process during storage (Poovaiah, 1979). Cicco et al. (2007) reported that kiwifruit firmness throughout the postharvest period could be

Received for publication 18 Feb. 2010. Accepted for publication 16 Apr. 2010.

${ }^{1}$ To whom reprint requests should be addressed; e-mail thosotir@otenet.gr. linked with $\mathrm{Ca}$ content. Kiwifruits sprayed before harvest with $\mathrm{CaCl}_{2}$ solutions exhibited lower softening rates compared with the controls at both 20 and $0{ }^{\circ} \mathrm{C}$ storage temperatures and their quality was maintained (Gerasopoulos et al., 1996). The role of Ca on the maintenance of cell membrane integrity and its cooperative role with boron (B) in the building of the plant cell wall is well documented (Yamaguchi et al., 1986). Although not all impacts of $\mathrm{Ca}$ on fruit quality appear to be positive, it is clear that $\mathrm{Ca}$ formulations, their rate, and timing of application affect the efficacy of $\mathrm{Ca}$ on several fruit quality attributes (Sotiropoulos et al., 2010).
The scope of the present research was to investigate the effect of various Ca-containing commercial products applied as foliar sprays on several fruit quality attributes and nutritional status of the kiwifruit cultivar Tsechelidis.

\section{Materials and Methods}

The research was conducted in a commercial kiwifruit [Actinidia deliciosa (A. chev.) C.F. Liang et A.R. Ferguson var. deliciosa] orchard in northern Greece. The vines of the cultivar Tsechelidis (Sotiropoulos et al., 2009) were 4 years old planted at a spacing $4 \times 3.5 \mathrm{~m}$ and trained in a T-bar trellis system.

Soil samples from the experimental orchard were collected from a depth of 0 to $60 \mathrm{~cm}$ and analyzed (Page et al., 1982). The soil was characterized as sandy loam, slightly alkaline ( $\mathrm{pH} 7.66)$, with low electrical conductivity $\left(0.61 \mathrm{mS} \cdot \mathrm{cm}^{-1}\right)$, high organic matter content $(2.93 \%)$, and average calcium carbonate content $(13.2 \%)$. Concerning nutrients in the soil, their concentrations were $\left(\mathrm{mg} \cdot \mathrm{kg}^{-1}\right)$ : phosphorus 45.4 , potassium $310, \mathrm{Ca} 413$, magnesium 21 , B 0.6 , manganese 12.5 , zinc 1.58 , and iron 20.8. Fertilization of the orchard was performed using soil and leaf analyses data. Three foliar sprays (with 10-d intervals) were applied by a hand sprayer starting at the beginning of June with the following products: 1) Calfruit (liquid calcium chloride, Ca 8.6\%) plus Qualyfruit [amino acids 15\%, total nitrogen (N) $6 \%$, organic N 3\%, organic matter 20\%] (AMC Chemicals and Trichodex S.A., Andalusia, Spain); 2) Power-Ca (Ca 14\%), (Nature S.A., Nea Efessos, Greece); 3) Profical [Ca 11\%, magnesium $(\mathrm{Mg}) 3 \%$, amino acids 12\%] (Nature S.A.); 4) Chelan Ca-P [Ca 13\%, phosphorus (P) 2.2\%, N 12\%] (Nature S.A.); 5) Basfoliar Combi Stipp [Ca 10.7\%, N 9\%, Mg $0.6 \%$, B $0.2 \%$, manganese $(\mathrm{Mn}) 0.4 \%$, zinc (Zn) $0.01 \%$ ] (Compo Hellas S.A., Athens, Greece); 6) Acid CaLMg (Ca 4.3\%, Mg $1.2 \%, \mathrm{~N} 6 \%$ ) (AMC Chemicals and Trichodex S.A., Andalusia, Spain); and 7) control (water sprayed).

The rates used were based on the suggestion of the producer industries: Power $\mathrm{Ca}$, Profical, Basfoliar Combi Stipp at a rate of $3 \mathrm{~L} \cdot \mathrm{t}^{-1}$, Chelan Ca-P at a rate of $2.5 \mathrm{~L} \cdot \mathrm{t}^{-1}$, Acid $\mathrm{CaLMg}$ at a rate of $2 \mathrm{~L} \cdot \mathrm{t}^{-1}$, and Calfruit at a rate of $2.5 \mathrm{~L} \cdot \mathrm{t}^{-1}$ plus Qualyfruit $1 \mathrm{~L} \cdot \mathrm{t}^{-1}$. In all treatments, B (Power 7-B) (10\% B) (Farma Chem S.A., Thessaloniki, Greece) was also added at a rate of $1 \mathrm{~L} \cdot \mathrm{t}^{-1}$. The addition of $\mathrm{B}$ was justified by its cooperative role with $\mathrm{Ca}$ in the building of the plant cell wall (Yamaguchi et al., 1986). A surfactant was also added in all treatments (shinulin: ethoxylated isodecyl alcohol; $0.3 \mathrm{~L} \cdot \mathrm{t}^{-1}$; Farma Chem S.A.). Leaf samples were collected at midsummer (20 July). Each leaf sample consisted of the third leaf past the final fruit on a lateral shoot. Fruit flesh analysis was carried out from samples taken at harvest. All samples were initially washed once with tap water and twice with distilled water. Leaf samples were dried in a forced draft oven at $68^{\circ} \mathrm{C}$ for $72 \mathrm{~h}$ and ground in a mill to pass a 30 -mesh screen. $\mathrm{N}$ was determined by the Kjeldahl procedure, 
B by the azomethine-H method (Wolf, 1974), $\mathrm{P}$ by the ammonium phosphovanadomolybdate method (Jackson, 1969), and potassium (K), $\mathrm{Ca}, \mathrm{Mg}$, iron ( $\mathrm{Fe}), \mathrm{Mn}$, and $\mathrm{Zn}$ by atomic absorption spectroscopy (Perkin-Elmer Model 2380, Wellesley, MA). Fruit samples (20 per replication) were collected mid-October (harvest period; $\approx 3.5$ months after the last spray). The following measurements were taken: mean fruit weight, flesh firmness (measured by an Effegi penetrometer 8-mm tip; Effegi, Milan, Italy), total soluble solids (measured with the Atago PR-1 electronic refractometer; Atago Co., Ltd., Tokyo, Japan), total titratable acidity [after titration with $0.1 \mathrm{~N}$ sodium hydroxide $(\mathrm{NaOH})]$, and ascorbic acid $(\mathrm{mg} / 100 \mathrm{~g}$ fresh weight) by oxalic acid (1\%) as described by Koukourikou-Petridou et al. (2007). In addition, ferric-reducing antioxidant power (Benzie and Strain, 1996) and total phenols (Singleton et al., 1999) were determined.

The experiment was conducted and repeated for 2 years. The adopted experimental design was a randomized block with five replications of seven treatments (eight vines per replication were used). Differences between means were evaluated by using the Duncan's multiple range test at $P \leq 0.05$.

\section{Results and Discussion}

None of the studied Ca products plus B affected mean fruit weight compared with the control for the 2 years (Table 1). During the first year, higher flesh firmness was measured after application of Acid CaLMg and Calfruit plus Qualyfruit (Table 1). During the second year, the highest flesh firmness was measured after application of Acid CaLMg (Table 1). In another experiment, kiwifruit plants (cv. Hayward) were sprayed up to three times during fruit development with $\mathrm{CaCl}_{2}$ (Gerasopoulos et al., 1996). Fruit firmness and acidity were increased, and soluble solids decreased after Ca sprays. Cicco et al. (2007) reported that fruit firmness throughout the postharvest period could be related to the $\mathrm{Ca}$ content of fruits. Low $\mathrm{Ca}$ concentrations in fruits have generally been found to accelerate the ripening process by stimulating the production of ethylene and by increasing the activity of enzymes, which are responsible for softening of the tissues (Poovaiah, 1979). Furthermore, a direct inhibitory effect of $\mathrm{Ca}$ on polygalacturonase was revealed (Cicco et al., 2007).

None of the studied $\mathrm{Ca}$ products significantly altered total soluble solids (both years) and acidity (second year) (Table 1). However, for the first year, the highest acidity was measured after application of Chelan $\mathrm{CaP}$. Furthermore, the highest ascorbic acid concentration was measured after application of Chelan $\mathrm{CaP}$. Total antioxidant power was higher after application of Chelan $\mathrm{CaP}$ than with Profical and Basfoliar combi stipp. Total phenols were higher after application of Power $\mathrm{Ca}$, Chelan $\mathrm{CaP}$, and the control treatment than with Profical, Basfoliar combi stipp, or Calfruit plus Qualyfruit (Table 1). A two-way analysis (including the year effect) on the effect of the fertilizers on fruit quality attributes revealed that only for fruit firmness were both main effects (year, fertilizer) significant $(P<0.01$ and $P<0.01$, respectively) as well as their interaction $(P<$ $0.05)$.

Nitrogen, $\mathrm{P}, \mathrm{Mg}, \mathrm{Fe}, \mathrm{Mn}$, and $\mathrm{Zn}$ concentrations of leaves were unaffected by the foliar sprays for both years (Table 2). Inclusion of Power 7-B in the sprays resulted in an increase of $\mathrm{B}$ concentrations of leaves compared with the control for both years (Table 2). Foliar application of Power-Ca resulted in an increase of $\mathrm{Ca}$ concentration of leaves compared with the control for the first year (Table 2).

Table 1. Kiwifruit weight, fruit firmness, total soluble solids, total titratable acidity, ascorbic acid, total antioxidant power, and total phenols during harvest.

\begin{tabular}{|c|c|c|c|c|c|c|c|}
\hline Treatments & $\begin{array}{l}\text { Mean } \\
\text { fruit } \\
\text { wt }(g)\end{array}$ & $\begin{array}{c}\text { Fruit } \\
\text { firmness } \\
\left(\mathrm{kg} \cdot \mathrm{cm}^{-2}\right)\end{array}$ & $\begin{array}{l}\text { Total soluble } \\
\text { solids ( }{ }^{\circ} \text { Brix) }\end{array}$ & $\begin{array}{l}\text { Total } \\
\text { titratable acidity } \\
(\% \text { citric acid })\end{array}$ & $\begin{array}{c}\text { Ascorbic acid } \\
(\mathrm{mg} / 100 \mathrm{~g} \text { fresh } \mathrm{wt})\end{array}$ & $\begin{array}{c}\text { Total antioxidant power } \\
\text { ( } \mu \text { mol ascorbic acid } \\
\text { equivalent/g fresh wt) }\end{array}$ & $\begin{array}{c}\text { Total phenols } \\
\text { (mg gallic acid } \\
\text { equivalent/g fresh wt) }\end{array}$ \\
\hline \multicolumn{8}{|l|}{ First year } \\
\hline Power $\mathrm{Ca}$ & $141.1 \mathrm{a}^{\mathrm{z}}$ & $7.21 \mathrm{bc}$ & $7.30 \mathrm{a}$ & $2.40 \mathrm{ab}$ & $86.70 \mathrm{~b}$ & $11.14 \mathrm{ab}$ & $24.50 \mathrm{a}$ \\
\hline Profical & $137.7 \mathrm{a}$ & $7.12 \mathrm{c}$ & $7.28 \mathrm{a}$ & $2.37 \mathrm{~b}$ & $81.30 \mathrm{c}$ & $10.70 \mathrm{bc}$ & $22.00 \mathrm{~b}$ \\
\hline Basfoliar Combi Stipp & $136.9 \mathrm{a}$ & $7.27 \mathrm{~b}$ & $7.23 \mathrm{a}$ & $2.32 \mathrm{~b}$ & $80.50 \mathrm{c}$ & $10.40 \mathrm{c}$ & $21.50 \mathrm{~b}$ \\
\hline Chelan CaP & $138.7 \mathrm{a}$ & $7.27 \mathrm{~b}$ & $7.22 \mathrm{a}$ & $2.47 \mathrm{a}$ & $91.35 \mathrm{a}$ & $11.20 \mathrm{a}$ & $24.30 \mathrm{a}$ \\
\hline Calfruit + Qualyfruit & $139.3 \mathrm{a}$ & $7.55 \mathrm{a}$ & $7.29 \mathrm{a}$ & $2.35 \mathrm{~b}$ & $84.90 \mathrm{~b}$ & $11.00 \mathrm{ab}$ & $22.48 \mathrm{~b}$ \\
\hline Acid CaLMg & $137.7 \mathrm{a}$ & $7.49 \mathrm{a}$ & $7.22 \mathrm{a}$ & $2.30 \mathrm{~b}$ & $85.20 \mathrm{~b}$ & $11.10 \mathrm{ab}$ & $23.30 \mathrm{ab}$ \\
\hline Control & $139.8 \mathrm{a}$ & $7.05 \mathrm{~d}$ & $7.23 \mathrm{a}$ & $2.31 \mathrm{~b}$ & $85.00 \mathrm{~b}$ & $11.00 \mathrm{ab}$ & $24.20 \mathrm{a}$ \\
\hline \multicolumn{8}{|l|}{ Second year } \\
\hline Power $\mathrm{Ca}$ & $137.8 \mathrm{a}$ & $6.58 \mathrm{~b}$ & $7.03 \mathrm{a}$ & $2.27 \mathrm{a}$ & & & \\
\hline Profical & $136.5 \mathrm{a}$ & $6.47 \mathrm{~b}$ & $7.05 \mathrm{a}$ & $2.20 \mathrm{a}$ & & & \\
\hline Basfoliar Combi Stipp & $134.5 \mathrm{a}$ & $6.63 \mathrm{~b}$ & $7.00 \mathrm{a}$ & $2.18 \mathrm{a}$ & & & \\
\hline Chelan CaP & $137.6 \mathrm{a}$ & $6.52 \mathrm{~b}$ & $6.98 \mathrm{a}$ & $2.18 \mathrm{a}$ & & & \\
\hline Calfruit + Qualyfruit & $137.2 \mathrm{a}$ & $6.66 \mathrm{~b}$ & $7.08 \mathrm{a}$ & $2.27 \mathrm{a}$ & & & \\
\hline Acid CaLMg & $139.6 \mathrm{a}$ & $7.33 \mathrm{a}$ & $6.96 \mathrm{a}$ & $2.24 \mathrm{a}$ & & & \\
\hline Control & $136.6 \mathrm{a}$ & $6.43 \mathrm{~b}$ & $7.01 \mathrm{a}$ & $2.22 \mathrm{a}$ & & & \\
\hline
\end{tabular}

${ }^{\mathrm{z}}$ Means followed by the same letter in the same column for each year are not significantly different (Duncan's multiple range test, $P \leq 0.05$ ).

Table 2. Effect of foliar sprays on nitrogen $(\mathrm{N})$, phosphorus $(\mathrm{P})$, potassium $(\mathrm{K})$, calcium $(\mathrm{Ca})$, magnesium $(\mathrm{Mg})$, boron $(\mathrm{B})$, manganese $(\mathrm{Mn})$, zinc $(\mathrm{Zn})$, and iron (Fe) concentration of the kiwifruit leaves during the 2 years of the experiment.

\begin{tabular}{|c|c|c|c|c|c|c|c|c|c|}
\hline Treatments & $\begin{array}{c}\mathrm{N} \\
\left(\mathrm{mg} \cdot \mathrm{g}^{-1}\right. \\
\text { dry } \mathrm{wt})\end{array}$ & $\begin{array}{c}\mathrm{P} \\
\left(\mathrm{mg} \cdot \mathrm{g}^{-1}\right. \\
\text { dry wt) }\end{array}$ & $\begin{array}{c}\mathrm{K} \\
\left(\mathrm{mg} \cdot \mathrm{g}^{-1}\right. \\
\text { dry wt) }\end{array}$ & $\begin{array}{c}\mathrm{Ca} \\
\left(\mathrm{mg} \cdot \mathrm{g}^{-1}\right. \\
\text { dry wt) }\end{array}$ & $\begin{array}{c}\mathrm{Mg} \\
\left(\mathrm{mg} \cdot \mathrm{g}^{-1}\right. \\
\text { dry wt) }\end{array}$ & $\begin{array}{c}\text { B } \\
\left(\mu g \cdot g^{-1}\right. \\
\text { dry wt) }\end{array}$ & $\begin{array}{c}\text { Mn } \\
\left(\mu g \cdot g^{-1}\right. \\
\text { dry wt) }\end{array}$ & $\begin{array}{c}\mathrm{Zn} \\
\left(\mu \mathrm{g} \cdot \mathrm{g}^{-1}\right. \\
\text { dry wt) }\end{array}$ & $\begin{array}{c}\text { Fe } \\
\left(\mu g \cdot g^{-1}\right. \\
\text { dry wt) }\end{array}$ \\
\hline \multicolumn{10}{|l|}{ First year } \\
\hline Power $\mathrm{Ca}$ & $2.03 \mathrm{a}^{\mathrm{z}}$ & $0.16 \mathrm{a}$ & $1.49 \mathrm{a}$ & $3.65 \mathrm{a}$ & $0.64 \mathrm{a}$ & $38 \mathrm{a}$ & $43 \mathrm{a}$ & $21 \mathrm{a}$ & $104 \mathrm{a}$ \\
\hline Profical & $1.99 \mathrm{a}$ & $0.18 \mathrm{a}$ & $1.31 \mathrm{c}$ & $3.28 \mathrm{c}$ & $0.68 \mathrm{a}$ & $41 \mathrm{a}$ & $46 \mathrm{a}$ & $21 \mathrm{a}$ & $101 \mathrm{a}$ \\
\hline Basfoliar Combi Stipp & $2.07 \mathrm{a}$ & $0.19 \mathrm{a}$ & $1.26 \mathrm{c}$ & $3.34 \mathrm{bc}$ & $0.64 \mathrm{a}$ & $40 \mathrm{a}$ & $41 \mathrm{a}$ & $20 \mathrm{a}$ & $103 \mathrm{a}$ \\
\hline Chelan CaP & $2.05 \mathrm{a}$ & $0.19 \mathrm{a}$ & $1.44 \mathrm{ab}$ & $3.50 \mathrm{ab}$ & $0.65 \mathrm{a}$ & $41 \mathrm{a}$ & $46 a$ & $21 \mathrm{a}$ & $105 \mathrm{a}$ \\
\hline Calfruit + Qualyfruit & $2.07 \mathrm{a}$ & $0.18 \mathrm{a}$ & $1.59 \mathrm{a}$ & $3.44 \mathrm{~b}$ & $0.62 \mathrm{a}$ & $39 a$ & $42 \mathrm{a}$ & $20 \mathrm{a}$ & $104 \mathrm{a}$ \\
\hline Acid CaLMg & $2.04 \mathrm{a}$ & $0.17 \mathrm{a}$ & $1.43 \mathrm{ab}$ & $3.51 \mathrm{ab}$ & $0.63 \mathrm{a}$ & $38 \mathrm{a}$ & $41 \mathrm{a}$ & $21 \mathrm{a}$ & $102 \mathrm{a}$ \\
\hline Control & $2.00 \mathrm{a}$ & $0.17 \mathrm{a}$ & $1.58 \mathrm{a}$ & $3.31 \mathrm{bc}$ & $0.65 \mathrm{a}$ & $30 \mathrm{~b}$ & $44 \mathrm{a}$ & $20 \mathrm{a}$ & $102 \mathrm{a}$ \\
\hline \multicolumn{10}{|l|}{ Second year } \\
\hline Power $\mathrm{Ca}$ & $1.82 \mathrm{a}$ & $0.18 \mathrm{a}$ & $1.71 \mathrm{~b}$ & $4.38 \mathrm{a}$ & $0.71 \mathrm{a}$ & $38 \mathrm{a}$ & $40 \mathrm{a}$ & $20 \mathrm{a}$ & $105 \mathrm{a}$ \\
\hline Profical & $1.81 \mathrm{a}$ & $0.17 \mathrm{a}$ & $1.62 \mathrm{bc}$ & $4.35 \mathrm{a}$ & $0.64 \mathrm{a}$ & $37 \mathrm{a}$ & $37 \mathrm{a}$ & $22 \mathrm{a}$ & $102 \mathrm{a}$ \\
\hline Basfoliar Combi Stipp & $1.86 \mathrm{a}$ & $0.18 \mathrm{a}$ & $1.57 \mathrm{c}$ & $4.25 \mathrm{~b}$ & $0.69 \mathrm{a}$ & $40 \mathrm{a}$ & $40 \mathrm{a}$ & $22 \mathrm{a}$ & $102 \mathrm{a}$ \\
\hline Chelan CaP & $1.83 \mathrm{a}$ & $0.17 \mathrm{a}$ & $1.68 \mathrm{~b}$ & $4.30 \mathrm{~b}$ & $0.64 \mathrm{a}$ & $41 \mathrm{a}$ & $38 \mathrm{a}$ & $21 \mathrm{a}$ & $110 \mathrm{a}$ \\
\hline Calfruit + Qualyfruit & $1.75 \mathrm{a}$ & $0.17 \mathrm{a}$ & $1.81 \mathrm{a}$ & $4.26 \mathrm{~b}$ & $0.68 \mathrm{a}$ & $38 \mathrm{a}$ & $42 \mathrm{a}$ & $23 \mathrm{a}$ & $103 \mathrm{a}$ \\
\hline Acid CaLMg & $1.79 \mathrm{a}$ & $0.16 \mathrm{a}$ & $1.61 \mathrm{bc}$ & $4.46 \mathrm{a}$ & $0.65 \mathrm{a}$ & 39 a & $39 \mathrm{a}$ & $21 \mathrm{a}$ & $107 \mathrm{a}$ \\
\hline Control & $1.82 \mathrm{a}$ & $0.18 \mathrm{a}$ & $1.76 \mathrm{ab}$ & $4.01 \mathrm{c}$ & $0.71 \mathrm{a}$ & $28 \mathrm{~b}$ & $40 \mathrm{a}$ & $22 \mathrm{a}$ & $103 \mathrm{a}$ \\
\hline
\end{tabular}

${ }^{\mathrm{z}}$ Means followed by the same letter in the same column for each year are not significantly different (Duncan's multiple range test, $P \leq 0.05$ ). 
Table 3. Effect of the foliar sprays on nitrogen $(\mathrm{N})$, phosphorus $(\mathrm{P})$, potassium $(\mathrm{K})$, calcium $(\mathrm{Ca})$, magnesium $(\mathrm{Mg})$, boron $(\mathrm{B})$, manganese $(\mathrm{Mn})$, zinc $(\mathrm{Zn})$, and iron $(\mathrm{Fe})$ concentration of the fruits during harvest of the first year of the experiment.

\begin{tabular}{|c|c|c|c|c|c|c|c|c|c|}
\hline Treatments & $\begin{array}{c}\mathrm{N} \\
\left(\mathrm{mg} \cdot \mathrm{g}^{-1}\right. \\
\text { dry } w \mathrm{t})\end{array}$ & $\begin{array}{c}\mathrm{P} \\
\left(\mathrm{mg} \cdot \mathrm{g}^{-1}\right. \\
\text { dry wt) }\end{array}$ & $\begin{array}{c}\mathrm{K} \\
\left(\mathrm{mg} \cdot \mathrm{g}^{-1}\right. \\
\text { dry wt) }\end{array}$ & $\begin{array}{c}\mathrm{Ca} \\
\left(\mathrm{mg} \cdot \mathrm{g}^{-1}\right. \\
\text { dry wt) }\end{array}$ & $\begin{array}{c}\mathrm{Mg} \\
\left(\mathrm{mg} \cdot \mathrm{g}^{-1}\right. \\
\text { dry wt) }\end{array}$ & $\begin{array}{c}\text { B } \\
\left(\mu g \cdot g^{-1}\right. \\
\text { dry wt) }\end{array}$ & $\begin{array}{c}\mathrm{Mn} \\
\left(\mu g \cdot g^{-1}\right. \\
\text { dry wt) }\end{array}$ & $\begin{array}{c}\mathrm{Zn} \\
\left(\mu \mathrm{g} \cdot \mathrm{g}^{-1}\right. \\
\text { dry wt) }\end{array}$ & $\begin{array}{c}\text { Fe } \\
\left(\mu g \cdot g^{-1}\right. \\
\text { dry wt) }\end{array}$ \\
\hline$\overline{\text { Power Ca }}$ & $0.95 \mathrm{a}^{\mathrm{z}}$ & $0.11 \mathrm{a}$ & $1.43 \mathrm{c}$ & $0.40 \mathrm{a}$ & $0.20 \mathrm{a}$ & $38 \mathrm{a}$ & $3 \mathrm{a}$ & $8 \mathrm{a}$ & $18 \mathrm{a}$ \\
\hline Profical & $1.00 \mathrm{a}$ & $0.11 \mathrm{a}$ & $1.53 \mathrm{ab}$ & $0.34 \mathrm{~b}$ & $0.17 \mathrm{a}$ & $40 \mathrm{a}$ & $3 a$ & $9 \mathrm{a}$ & $17 \mathrm{a}$ \\
\hline Basfoliar Combi Stipp & $0.99 \mathrm{a}$ & $0.12 \mathrm{a}$ & $1.41 \mathrm{c}$ & $0.38 \mathrm{ab}$ & $0.17 \mathrm{a}$ & $39 \mathrm{a}$ & $4 \mathrm{a}$ & $8 \mathrm{a}$ & $16 \mathrm{a}$ \\
\hline Chelan CaP & $0.94 \mathrm{a}$ & $0.12 \mathrm{a}$ & $1.44 \mathrm{c}$ & $0.40 \mathrm{a}$ & $0.19 \mathrm{a}$ & $40 \mathrm{a}$ & $3 a$ & $9 \mathrm{a}$ & $17 \mathrm{a}$ \\
\hline Calfruit + Qualyfruit & $0.96 \mathrm{a}$ & $0.12 \mathrm{a}$ & $1.59 \mathrm{a}$ & $0.42 \mathrm{a}$ & $0.20 \mathrm{a}$ & $37 \mathrm{a}$ & $3 \mathrm{a}$ & $9 \mathrm{a}$ & $18 \mathrm{a}$ \\
\hline Acid CaLMg & $0.97 \mathrm{a}$ & $0.11 \mathrm{a}$ & $1.50 \mathrm{~b}$ & $0.40 \mathrm{a}$ & $0.19 \mathrm{a}$ & $37 \mathrm{a}$ & $3 \mathrm{a}$ & $8 \mathrm{a}$ & $17 \mathrm{a}$ \\
\hline Control & $1.00 \mathrm{a}$ & $0.12 \mathrm{a}$ & $1.55 \mathrm{a}$ & $0.32 \mathrm{~b}$ & $0.18 \mathrm{a}$ & $25 \mathrm{~b}$ & $4 \mathrm{a}$ & $9 \mathrm{a}$ & $16 \mathrm{a}$ \\
\hline
\end{tabular}

${ }^{\mathrm{z}}$ Means followed by the same letter in the same column are not significantly different (Duncan's multiple range test, $P \leq 0.05$ ).

The higher effectiveness of Power-Ca may be mainly the result of its formula, which contains Ca complexed with sugar polyalcohols facilitating the transportation of $\mathrm{Ca}$ within the plant. During the second year, all Ca products increased $\mathrm{Ca}$ concentration of leaves compared with the control (Table 2). However, higher leaf $\mathrm{Ca}$ concentrations were measured after application of Power-Ca, Acid CaLMg, and Profical. Application of Profical (first year) and Basfoliar combi stipp (both years) resulted in a decrease of $\mathrm{K}$ concentration of leaves compared with the control (Table 2). A two-way analysis (including the year effect) on the effect of the fertilizers on leaf nutrient concentrations revealed that for $\mathrm{Ca}$, main effects (year, fertilizer) were both significant $(P<0.01$ and $P<0.001$, respectively $)$ as well as their interaction $(P<0.01)$. With regard to $\mathrm{K}$ and $\mathrm{B}$, only the fertilizer effect was significant, whereas the year effect and the interaction were not significant.

Nitrogen, $\mathrm{P}, \mathrm{Mg}, \mathrm{Fe}, \mathrm{Mn}$, and $\mathrm{Zn}$ concentrations of fruits were unaffected by the foliar sprays (Table 3). Inclusion of Power 7-B resulted in an increase of $B$ concentrations of fruits compared with the control. Foliar application of Calfruit plus Qualyfruit, Chelan CaP, Power $\mathrm{Ca}$, and Acid CaLMg resulted in an increase of $\mathrm{Ca}$ concentration of fruits compared with the control. In vines sprayed 17 times with $\mathrm{CaCl}_{2}$ at $0.8 \%$ commercial product (1700 ppm Ca), fruit $\mathrm{Ca}$ content was higher and its storage life $50 \%$ to $80 \%$ longer than that from vines sprayed nine times and from control vines (Cooper et al., 2007). Also, $\mathrm{CaCl}_{2}$ sprays increased fruit pericarp, core, and skin $\mathrm{Ca}$ concentration of kiwifruit as reported by Gerasopoulos et al. (1996). Foliar application of Power $\mathrm{Ca}$, Basfoliar combi stipp, Chelan $\mathrm{CaP}$, and Acid CaLMg resulted in a decrease of $\mathrm{K}$ concentration of fruits compared with the control, probably as a result of an antagonistic effect of $\mathrm{Ca}$ on K. Montanaro et al. (2006) reported that $\mathrm{Ca}$ concentration in fruits of the cv. Hayward at harvest was $0.24 \%$ (dry matter). In our experiment, $\mathrm{Ca}$ concentration of the $\mathrm{cv}$. Tsechelidis was $0.21 \%$ (dry matter). As reported by Sotiropoulos et al. (2009), leaf N and fruit flesh $\mathrm{N}$ and $\mathrm{P}$ were significantly lower, whereas leaf $\mathrm{K}$, fruit skin $\mathrm{P}, \mathrm{K}$, and $\mathrm{Mn}$, and fruit flesh Mn were higher in 'Tsechelidis' than 'Hayward'.

In kiwifruit, xylem functionality, fruit transpiration, fruit hair viability, and fruit hydraulic conductance showed significant changes during the first 8 to 10 weeks after full bloom
(Xiloyannis et al., 2008). The early cessation of $\mathrm{Ca}$ import into the fruit may be ascribed to the previous parameters. Xylem transport occurs only in the acropetal direction and is of some importance for the Ca supply of young fruits, which still transpire in the early phase of their development. At a later stage, fruits almost exclusively feed through the phloem (Epstein and Bloom, 2005). The phloem transport system is through cytoplasm, which has low concentrations of Ca (Raven, 1977). As a result of its phloem immobility, the foliage-applied $\mathrm{Ca}$ is not redistributed from treated leaves to the fruit (Swietlik and Faust, 1984). B mobility in kiwifruit is also considered low (Brown and $\mathrm{Hu}, 1998)$. Schonherr (2001) studying the cuticular penetration using $\mathrm{Ca}$ salts found that the rates of penetration were greatly affected by humidity over cuticles and hygroscopicity of salts. Penetration of the ions required dissolution of the salt and this was determined by the point of deliquescence (POD) of the salt and humidity over the salt residue. Schonherr (2001) concluded that salts suitable for foliar nutrition should have a low POD such as $\mathrm{CaCl}_{2}$ $(33 \%)$ and $\mathrm{Ca}\left(\mathrm{NO}_{3}\right)_{2}(56 \%)$. Salts having $\mathrm{POD}$ above $90 \%$ (for example, Ca-acetate, $\mathrm{Ca}$ lactate, and Ca-propionate) are not suitable for foliar nutrition, because they penetrate only at humidity levels close to $100 \%$.

The enrichment of some products with $\mathrm{N}$ and amino acids may have affected foliar absorption because it is reported that urea facilitates the simultaneous influx of other nutrients at both the cuticular and cellular levels (Weinbaum, 1988). Phloem transport of $\mathrm{N}$ occurs mainly in the form of amino acids. The nitrogen of urea, ammonium, or nitrate in foliar sprays has to be transformed into amino$\mathrm{N}$ before it is subjected to long-distance phloem transport (Mengel, 2002). Various commercial products are available containing various amino acids. Furuya and Umemiya (2002) studied 18 kinds of foliar applied $\mathrm{N}$ chemical forms for the absorption of $\mathrm{N}$ into peach leaves. They stated that urea and inorganic $\mathrm{N}$ sources, especially nitrate-N, were superior as compared with amino acids regarding $\mathrm{N}$ absorption into the peach leaves.

In conclusion, the application of the studied commercial $\mathrm{Ca}$ products was beneficial to the fruit firmness, especially the first year and in some treatments to the fruit $\mathrm{Ca}$ concentration. It seems that the composition and the form of $\mathrm{Ca}$ (organic, inorganic, etc.) of these products exert a significant role on the absorption and transportation of $\mathrm{Ca}$ within the plants.
The efficiency of the foliar sprays on some of the tested parameters varied from year to year indicating the influence of other parameters on vine nutrition. Some differences noticed between the 2 years of the study on the efficacy of the various $\mathrm{Ca}$ commercial products may have been probably ascribed to the effect of the first year treatment on the second, on the crop load (higher in the second year), the climatic conditions (temperature, relative humidity), etc.

\section{Literature Cited}

Basiouny, F.M. and A. Basiouny. 2000. Effects of liquid calcium and controlled atmosphere on storability and quality of kiwifruit (Actinidia chinensis Planch cv. Hayward). Acta Hort. 518: 213-221.

Benzie, I.F. and J. Strain. 1996. The ferric reducing ability of plasma (FRAP) as a measure of 'antioxidant power': The FRAP assay. Anal. Biochem. 44:276-287.

Brown, P.H. and H. Hu. 1998. Phloem boron mobility in diverse plant species. Bot. Acta 111: 331-335.

Cicco, N., B. Dichio, C. Xiloyannis, A. Sofo, and V. Lattanzio. 2007. Influence of calcium on the activity of enzymes involved in kiwifruit ripening. Acta Hort. 753:433-438.

Cooper, T., A. Gargiullo, J. Streif, and J. Retamales. 2007. Effects of calcium content and calcium applications on softening of Hayward kiwifruit. Acta Hort. 753:297-304.

Epstein, E. and A. Bloom. 2005. Mineral nutrition of plants: Principles and perspectives. 2nd Ed. Sinauer Associates, Sunderland, MA.

Furuya, S. and Y. Umemiya. 2002. The influence of chemical forms on foliar-applied nitrogen absorption for peach trees. Acta Hort. 594:97103.

Gerasopoulos, D., V. Chouliaras, and S. Lionakis. 1996. Effects of preharvest calcium chloride sprays on maturity and storability of Hayward kiwifruit. Postharvest Biol. Technol. 7:65-72.

Jackson, D.I. 1969. Soil chemical analysisAdvanced course. 2nd Ed. University of Wisconsin, Madison, WI.

Koukourikou-Petridou, M., D. Voyatzis, D. Stylianidis, T. Sotiropoulos, and I. Therios. 2007. Effects of some growth regulators on pre and after storage quality of Red Chief Delicious apples. Eur. J. Hort. Sci. 72:8-11.

Mengel, K. 2002. Alternative or complementary role of foliar supply in mineral nutrition? Acta Hort. 594:33-47.

Montanaro, G., B. Dichio, C. Xiloyannis, and G. Celano. 2006. Light influences transpiration and calcium accumulation in fruit of kiwifruit plants (Actinidia deliciosa var. deliciosa). Plant Sci. 170:520-527.

Page, A.L., R.H. Miller, and D.R. Keeney. 1982. Chemical and microbiological properties, $\mathrm{p}$. 
431-436. In: Page, A.L., R.H. Miller, and D.R. Keeney (eds.). Methods of soil analysis. ASASSSA, Madison, WI.

Poovaiah, B. 1979. Role of calcium in ripening and senescence. Commun. Soil Sci. Plant Anal. 10: 83-88.

Raven, J.A. 1977. $\mathrm{H}^{+}$and $\mathrm{Ca}^{2+}$ in phloem and symplast: Relation of relative immobility of the ions to the cytoplasmic nature of the transport paths. New Phytol. 79:465-480.

Schonherr, J. 2001. Cuticular penetration of calcium salts: Effects of humidity, anions, and adjuvants. J. Plant Nutr. Soil Sci. 164:225231.

Singleton, V.L., R. Orthofer, and R. LamuelaRaventos. 1999. Analysis of total phenols and other oxidation substrates and antioxidants by means of Folin-Ciocalteu reagent. Methods Enzymol. 229:152-178.

Sotiropoulos, T., M. Koukourikou-Petridou, A. Petridis, D. Stylianidis, D. Almaliotis, I. Papadakis, I. Therios, and A. Molassiotis. 2009. Tsechelidis kiwifruit. HortScience 44 466-468.

Sotiropoulos, T., I. Therios, and N. Voulgarakis. 2010. Effect of various foliar sprays on some fruit quality attributes and leaf nutritional status of the peach cultivar 'Andross'. J. Plant Nutr. 33:471-484

Swietlik, D. and M. Faust. 1984. Foliar nutrition of fruit crops. Hort. Rev. (Amer. Soc. Hort. Sci.) 6: 287-355.
Weinbaum, S.A. 1988. Foliar nutrition of fruit trees, p. 81-100. In: Neumann, P.N. (ed.). Plant growth and leaf applied chemicals. CRC Press, Boca Raton, FL.

Wolf, B. 1974. Improvement in the azomethine-H method for the determination of boron. Commun. Soil Sci. Plant Anal. 5:39-44.

Xiloyannis, C., B. Dichio, G. Montanaro, A. Lang, G. Celano, and M. Mazzeo. 2008. Fruit morphological and physiological traits influence calcium transport and accumulation in kiwifruit. Acta Hort. 767:369-377.

Yamaguchi, T., T. Hara, and Y. Sonoda. 1986. Distribution of calcium and boron in the pectin fraction of tomato leaf cell wall. Plant Cell Physiol. 27:729-732. 